\title{
A Review of Centriole Activity, and Wrongful Activity, during Cell Division
}

\author{
Ronald L. Huston \\ Department of Mechanical and Materials Engineering, University of Cincinnati, Cincinnati, OH, USA \\ Email: ron.huston@uc.edu
}

Received 1 February 2016; accepted 27 March 2016; published 30 March 2016

Copyright (C 2016 by author and Scientific Research Publishing Inc.

This work is licensed under the Creative Commons Attribution International License (CC BY). http://creativecommons.org/licenses/by/4.0/

(c) (i) Open Access

\section{Abstract}

This is a review paper on centriole behavior and their role in enabling cell division and duplication. The paper is based primarily on articles published in this, the $21^{\text {st }}$ century. Following a description of centriole geometry, the paper discusses centriole duplication and the ensuring events leading to cell division. From a structural perspective each centriole is seen to be a cylindrical composition of nine blades, each having three microtubules which are themselves hollow cylinders approximately $400 \mathrm{~nm}$ long, with inner and outer diameters of 15 and $25 \mathrm{~nm}$. The paper then discusses the nucleation of these microtubules. The paper concludes with a description of centriole malfunction and overduplication (supernumerary centrioles), leading to clusters of centrioles -a hallmark of cancer cells. These centriole clusters thus form "biomarkers" for tumor imaging and treatment.

\section{Keywords}

Centrioles, Cancer, Mitosis, Microtubules

\section{Introduction}

This paper presents a selective review of some recently published research findings about centrioles, their duplication, and then their role in cell duplication. The paper also focuses on centriole defects and the potential development of tumors.

The research cited is primarily that published in this, the $21^{\text {st }}$ century. As with most reviews there are undoubtedly important writings that are overlooked, or inadvertently omitted. I sincerely regret any such omissions. Also, some of the material presented herein is rudimentary, establishing a basis for describing the new findings.

The balance of the paper is divided into eight sections with the first of these being a general description of centrioles themselves. The next section briefly describes how centrioles are duplicated. The third section describes 
the role of centrioles in cell division (mitosis).

The next two sections provide a closer look at centriole geometry and how it is developed. Sections 6 and 7 then discuss erratic centriole development leading to tumorigenesis and malignant cells.

Finally, the last section provides a summary of what are believed to be the most important findings for going forward, and some concluding remarks.

The paper has 172 references which can also serve as a bibliography for research on open questions identified in the paper.

\section{Centrioles}

Centrioles are small organelles lying adjacent to the nucleus in human and animal (eukaryotic) cells [1]-[11]. From a small distance away centrioles appear to be a pair of short hollow cylinders perpendicular to each other. Their length is approximately $0.4 \mu \mathrm{m}(400 \mathrm{~nm})$ and their diameter approximately $0.2 \mu \mathrm{m}(200 \mathrm{~nm})$.

But up close, centrioles are seen to be a set of 9 open (uncovered) inclined blades arranged around the circumference. Each of these blades in turn is composed of three hollow cylinders known as "microtubules", whose outside diameter is approximately $25 \mathrm{~nm}$ and inside diameter approximately $15 \mathrm{~nm}$.

Figures 1-3 provide drawings of a cell, of centrioles and of microtubules [1] [11].



Figure 1. Cell interior showing centriole near the nucleus.

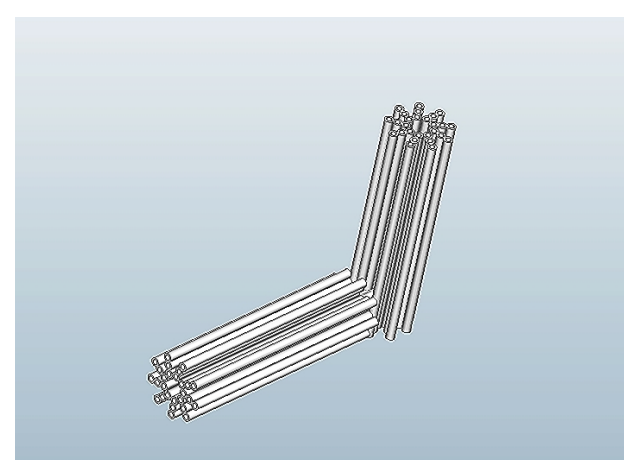

Figure 2. Centriole pair.

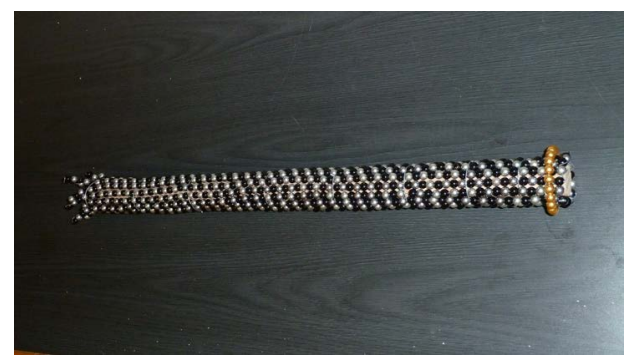

Figure 3. A microtubule. 
As seen in Figure 2, the two centrioles are not identical: instead one, known as the "mother", is slightly longer than the other (the "daughter"). Also, the daughter has its base attached to the side at the base of the mother. The ends, at the connection of the centrioles are known as the "proximal" ends, with the other ends thus being "distal".

The proximal ends are believed to be immersed in a cloud of "electron dense" matter [7] [8] [12]-[16]. Therefore, from an electrical perspective, the proximal ends have a negative charge, and the distal ends then have a positive charge.

The nine sets of microtubule blades are the "building blocks" and principal structure of the centrioles. Figure 3 provides a more detailed drawing of the individual microtubules. They are composed of 13 lateral filaments made up of tubulin dimers (alpha and beta tubulin attached to each other as batteries in series). The dimers are approximately $8 \mathrm{~nm}$ long and $5 \mathrm{~nm}$ thick. Observe that the filaments of dimers being odd (13) in number prevents them from being packed tight around the circumference since with tight packing the symmetry around the circumference would be disrupted.

Centrioles were originally discovered with the advent of microscopy in the beginning of the $20^{\text {th }}$ century (circa 1904) [2] [17]-[26]. For many years the purpose of centrioles and their function were unknown. Shortly after the mid-twentieth century, with the development of electron microscopy, the behavior of centrioles was studied and exposited by Paul Schafer [18] [19] [21]. But unfortunately this work was largely ignored since researchers began to focus upon then findings of Watson and Krick about DNA [27]. Also, others regarded centrioles as being relatively unimportant since they do not occur in plant cells or in bacteria.

Near the beginning of the $21^{\text {st }}$ century, however, it became generally accepted that centrioles were the principal organelles driving cell division and duplication (mitosis) in eukaryotic cells (human and animal cells) despite being absent in prokaryotic cells (bacteria) and in plants.

But what is now stimulating interest in researchers is that excessive centrioles and centrioles with distorted geometries are now being seen as the initiators of tumors [17] [28]-[60].

\section{Centriole Duplication}

When the centrioles begin to duplicate, the mother and daughter separate slightly and then each centriole begins to form a new centriole at its base: the mother with a new daughter and the daughter with a new daughter of its own (a "granddaughter"). As the pair of centrioles are developing daughters, and continue to separate from each other, the original pair becomes two pair. In this way the centrioles duplicate each other [1] [4] [8] [28] [35] [55] [57] [61]-[90].

As the centriole duplication is happening, the DNA of the nucleus is also being duplicated and separated. That is, the current research shows that centriole duplication and DNA separation are, in some way, entangled. [15] [22] [91]-[97].

\section{Mitosis (Cell Duplication and Division)}

Following centriole duplication and separation into two pair, the younger pair moves around the nucleus to the opposite side. While this is occurring, the nuclear membrane begins to soften. The centrioles at the opposite sides of the nucleus then begin to pull the nucleus apart.

As the nucleus is being elongated the microtubules of the centrioles extend and align themselves along the long axis of the nucleus, forming the "mitotic spindle" [61] [83] [98]-[102], as represented in Figure 4. The nucleus then shrinks in the middle and eventually separates into two parts. During their separation, each part takes approximately half of the remainder of the cell (the cytoplasm) with it. The result of this process, known as "cytokinesis", is then two twin-like cells.

The mitotic process is frequently described in terms of an initiating phase, known as "interphase" followed by four development phases. It is during this interphase that the centrioles duplicate and the DNA divides: Just before the duplication and division there is a relatively inactive period, or gap, called "G1". Following G1 is the "S-phase", where the centrioles duplicate and the DNA divide. The interphase then becomes complete with a second gap period called "G2".

In the first of the four development phases, known as "Phase I" or "Prophase", the chromosomes condense, drawing close together, and the nuclear membrane begins to dissolve and weaken. At the same time the mitotic spindle forms with the now separated centriole pairs of the spindle ends. In Phase II, called "Metaphase", the 


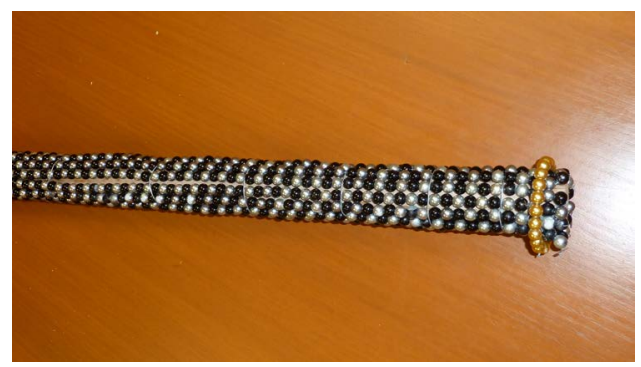

Figure 4. Microtubule spindle.

chromosome strings move toward and align themselves with the axis of the mitotic spindle. In Phase III, called "Anaphase", the chromosome strings divide and move toward opposite ends of the elongating spindle. Finally, in Phase IV, known as "Telophase", new nuclear membranes form about the separated chromosome strings, the mitotic spindle breaks apart and the cell separation begins completion with half the cytoplasm going with each new nucleus [1] [9]-[11].

The centriole pairs at either end of the mitotic spindle appear to be driving influences during this entire cell division process. Moreover these influences appear to be occurring due to forces exerted at a distance via the centrioles electromagnetic fields [4] [5] [63] [91] [99] [103]-[105].

\section{Centriole Geometry and the Centrosome}

Unlike all other organelles, or for that matter, any organ of the body, the centrioles have precise "straight-line" geometry and symmetry; and the centriole cylinders are exactly perpendicular to each other.

Also, unlike other organelles and organs, centrioles have no membrane cover. They are primarily a structural organization of microtubule blades-nine sets of triplets arranged uniformly about the centriole axis.

The centrioles are immersed in a cloud of proteins—-perhaps as many as 300 or more [8] [63] [93] [106]-[108]. These proteins are coiled, twisted bands, with an approximate overall spherical shape. Taken together this protein "cloud" is known as the microtubule organizing center (MTOC), since it provides the protein for microtubule growth and structure. The MTOC is also known as "pericentriolar material". The centriole pair together with the surrounding MTOC is known as the "centrosome".

The centrosome is approximately $1 \mu \mathrm{m}$ in diameter and the centrioles are at the core of the centrosome. As noted earlier the proteins of the centrosome at the base intersection of the centrioles are believed to be "electron dense" and therefore the centriole base is assigned negative polarity.

\section{Centriole Development during Interphase}

While details of centriole development are still being discovered, it appears that only a few of the many proteins in the centrosome are primarily involved. The remainder probably plays supportive roles.

The primary proteins are: Plk1 (polo-like kinase one), Plk4 [also known as (aka) "SAK"], asterless (AsP), SAS4, SAS6, ZYG-1, STIL (aka "SIL"), p53, separase, Cdk2, Cyclin E, and $\alpha, \beta$, and $\gamma$-tubulin [4]-[7] [24] [47] [52] [61] [63] [65] [66] [68] [74] [77]-[80] [82]-[86] [88] [91] [95] [97]-[99] [109]-[134].

What appears to occur is that just prior to the creation of a new centriole ("daughter" centriole) near the base of an existing centriole ("mother" centriole), AsP attaches itself to one of the nine outside microtubule blades [79] [80] [88] [131] [135], The AsP then recruits Plk4 to deposit itself atop the AsP, and then expand to being a base for ensuing structure. While this is happening SIL recruits SAS6 to the Plk4 base. The SAS6 then begins to expand symmetrically, tangent to the mother's outside microtubule surface. In this expansion the SAS6 forms nine spokes which become the platform for the daughter centriole. The platform then recruits $\gamma$-tubulin to its center, and the $\gamma$-tubulin in turn recruits $\alpha$ and $\beta$-tubulin for the structural elements of the microtubules. The $\alpha$ and $\beta$-tubulin link together forming a dimer and the dimers connected end-to-end form a longitudinal filament of a microtubule (see Figure 5).

SAS4 and yet another protein, Bld10/CEP135, appear to aid in recruiting the tubulin to the centriole base. The process is controlled and regulated by SAS4 itself, together with ZYG-1, and p53 [7] [15] [35] [46] [52] [57] [63] [69] [72] [74] [98] [116]-[118] [123] [125] [129] [130] [132] [133] [136]-[153]. 


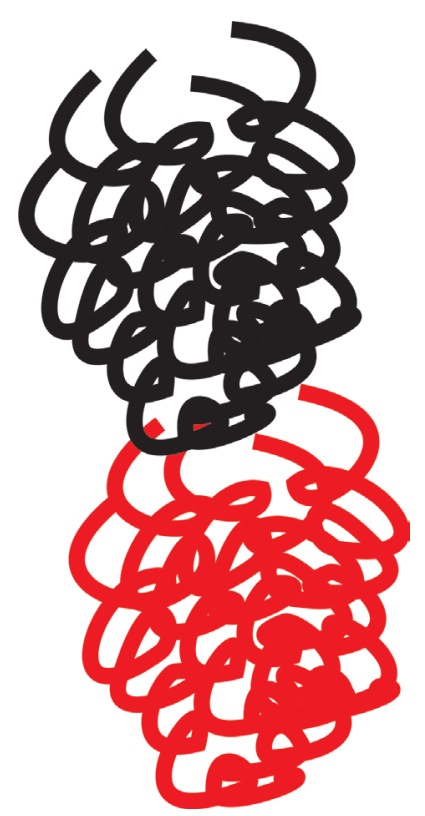

Figure 5. A microtubule dimer $(\alpha$-red, $\beta$ black).

Once the daughter centriole size grows to approximately $80 \%$ of that of the mother centriole, they form a new mother-daughter centriole pair. This pair is a duplicate of an adjacent similarly forming centriole pair.

Proteins Plk1, separase, cdk2, and cyclin E then promote the separation of the two centriole pairs. Plk1 is also active in dividing the surrounding centrosome protein between the original mother-new daughter pair and the original daughter-new "granddaughter".

As the centriole pairs are separating the new daughter centrioles become mature [100].

CPAP and SAS4 are similar as are ZYG-1 and Plk4. But of all the proteins it appears that Plk4 is the most involved in new centriole initiation and growth, in that Plk4 is the primary base for the new centriole.

\section{Wrongful Centriole Development}

While the foregoing description of centriole development is neither comprehensive nor necessarily accurate in all detail, it is clear that centriole development is quite complex. Due to this complexity there are many ways the process can go awry - even though a number of proteins are thought to be regulatory. For example, if there is an imbalance in the ratio of the proteins, the daughter centriole may be defective. Here are some examples of such defects.

1) The centriole geometry can get distorted. The axes of a pair can deviate from perpendicularity.

2) Multiple daughter centrioles may develop.

3) The daughter centriole may reach full length before pair separation.

4) Separation of the pairs and their disengagement may be delayed.

When there is a wrongful, or erroneous, supplication of centrioles either via geometrical defects and/or multiple duplication, the cells can become damaged and even malignant. The DNA can be damaged leading to aneuploidy (an abnormal number of chromosomes). That is, the DNA replication is altered leading to chromosome instability (CIN).

In what may be the same phenomena, it is known that centrosome defects (for example, an enlarged centrosome) leads to CIN. An enlarged centrosome is known to promote the development of multiple daughter centrioles [34] [60] [85] [88] [93] [95] [116] [140] [141] [154]-[163].

Doxey says: "Indeed, it would seem that the answer to some of the big questions of tumorgenesis are hiding in small places like the centrosomes" [47].

Finally, regarding the proteins underlying these wrongful activities, it seems that a dearth of p53 allows for deregulation of the centriole duplication and development process, allowing it to go awry. Also an overexpres- 
sion of Plk4 and SAS6 can lead to centrosome amplification. Alternatively, too little Plk4 and SAS6 can lead to duplication error. More research is needed to obtain a clearer understanding of these effects.

\section{Abnormal Centrioles and Malignant Cells}

Centriole and centrosome abnormalities lead to either: 1) self-correction due to regulatory proteins: 2) cell death; or 3) tumor generation ("tumorigenesis") when there is tumorigenesis, the centrioles tend to have multiple daughters regulating in a proliferation of centrioles [7] [12] [14] [17] [28]-[31] [37] [52]-[54] [58] [59] [61] [62] [70] [72] [75] [109] [112] [113] [115] [116] [118] [127] [158] [161] [162] [164]-[168], or so-called "supernumerary centrioles”.

The precise mechanisms producing supernumerary centrioles is not yet clearly understood-although the over duplication appears to occur in the S-phase. When supernumerary centrioles appear, abnormal mitosis occurs and tumors develop.

In addition, when there are supernumerary centrioles, the cell polarity (cell shape) is disturbed.

Supernumerary centrioles lead to centrosome amplification which is a "hallmark" of cancer cells.

The supernumerary centrioles tend to cluster together leading to centrosome clustering which appear to be essential for the survival of damaged cells.

The characteristics of cells with supernumerary centrioles include:

1) An excess of pericentriolar material.

2) Disrupted cylindrical structure of the centrioles.

3) Centrioles with excessive length.

4) Non-perpendicular centrioles.

5) Mispositioned centrioles.

It has been suggested that centriole and centrosome clusters in cancer cells might serve as a target or "biomarker" for imaging and therapeutic agents, such as super-paramagnetic nanoparticles [7] [32] [169] [170]. More research is needed to explore this promising approach.

\section{Summary and Conclusions}

From the beginning of the $21^{\text {st }}$ century, centriolar studies have and are becoming increasingly important in the minds of cell biologists, physicists, chemists and medical researchers. This is remarkable in that only a couple of decades ago centrioles were largely regarded as relatively unimportant, or even perhaps unessential for cell division.

The studies cited in this review, however, reveal that centrioles appear to be as important as DNA duplication in eukaryotic cell mitosis.

Here are the principal findings:

1) There are two reasons for this increased interest in centriole behavior: a) There is now better imaging technology revealing the importance of centriole activity; and b) Abherrent centriole activity is seen to be the basis for tumorigenesis.

2) Centrioles are the only organelle in biological systems with virtually exact geometry: that is, straight-line perpendicular and circular. This near-perfect geometry is due to the parallel arrangement of nine blades of triplet microtubules forming the centriole cylinder, whose axis is perpendicular to its centriole mother's axis.

3) The duplication and separation of a centriole pair occurs in the S-phase of the eukaryotic cycle, and at the same time as the DNA and chromosome duplication and separation.

4) New centriole development via microtubule growth is stimulated and regulated by a collection of proteins whose complete number and roles are not yet fully known.

5) Of all the proteins involved in microtubule development, Plk4 (polo-like kinase 4) appears to be the most prominent.

6) An excess or dearth of one or more of the major proteins involved in centriole duplication can lead to structural errors resulting in cell death or aggressive cell development and tumorigenesis.

7) Virtually all cancer cells have supernumerary, or multiple, centrioles. These multiple centrioles tend to cluster together [103]-[105] [171] [172].

8) A cluster of centrioles in a cancer cell is likely to produce a greater magnetic field than a single pair of centrioles in a normal cell. Evidence of this increased magnetism of centriole clusters is seen in increased electro- 
magnetic activity of breast cancer cells which can even be measured externally [106]-[108] [171] [172].

9) An increased magnetic field about a centriole cluster in a cancer cell is a "biomarker" or target for tumor imaging and therapy.

These findings provide a documented oasis for additional studies-particularly in the area of cellular electromagnetic properties and their potential use for tumor imaging and therapy.

\section{Acknowledgements}

Partial support for this research was provided by the Schafer Foundation and is sincerely appreciated. Also, the consultation of Bardyl Tirana and Roger Adelman is acknowledged.

\section{References}

[1] Alberts, B., Bray, D., Lewis, J., Raff, M., Roberts, K. and Watson, J.D. (1994) Molecular Biology of the Cell. 3rd Edition, Garland Publishing, New York.

[2] Bornens, M. (2012) The Centrosome in Cells and Organisms. Science, 335, 422-426. http://dx.doi.org/10.1126/science.1209037

[3] Doxey, S. (2001) Re-Evaluating Centrosome Function. Nature Reviews Molecular Cell Biology, 2, 688-698. http://dx.doi.org/10.1038/35089575

[4] Lange, B.M. and Gull, K. (1996) Structure and Function of the Centriole in Animal Cells: Progress and Questions. Trends in Cell Biology, 6, 348-352. http://dx.doi.org/10.1016/0962-8924(96)10033-7

[5] Mahen, R. and Venkitaraman, A.R. (2012) Pattern Formation in Centrosome Assembly. Current Opinion in Cell Biology, 24, 14-23. http://dx.doi.org/10.1016/j.ceb.2011.12.012

[6] Jana, S.C., Marteil, G. and Bettencourt-Dias, M. (2014) Mapping Molecules to Structure: Unveiling Secrets of Centriole and Cilia Assembly with Near-Atomic Resolution. Current Opinion in Cell Biology, 26, 96-106. http://dx.doi.org/10.1016/j.ceb.2013.12.001

[7] Loncarek, J. and Khodjakov, A. (2009) Ab Ovo or De Nous? Mechanisms of Centriole Duplication. Molecules and Cells, 27, 135-142. http://dx.doi.org/10.1007/s10059-009-0017-z

[8] Bettencourt-Dias, M. and Glover, D.M. (2007) Centrosome Biogenesis and Function: Centrosomics Brings New Understanding. Nature Reviews, Molecular Cell Biology, 8, 451-463. http://dx.doi.org/10.1038/nrm2180

[9] Marieb, E.N. (1991) Human Anatomy and Physiology. 3rd Edition, Benjamin/Cummings Publishing, Redwood City, CA, Chapter 3, 60-101.

[10] Guest, D. (1996) Biology Smart, The Princeton Review. Random House, New York, 133-135.

[11] Hardin, J., Bertoni, G. and Kleinsmith, L.J. (2015) Becker’s World of the Cell. Eighth Ed., Pearson.

[12] Lingle, W.L. and Salisbury, J.L. (1999) Altered Centrosome Structure Is Associated with Abnormal Mitoses in Human Breast Tumors. American Journal of Pathology, 155, 1941-1951. http://dx.doi.org/10.1016/S0002-9440(10)65513-7

[13] Bärenz, F., Mayilo, D. and Gruss, O.J. (2011) Centriolar Satellites: Busy Orbits around the Centrosome. European Journal of Cell Biology, 90, 983-989. http://dx.doi.org/10.1016/j.ejcb.2011.07.007

[14] Cunha-Ferreira, I., Bento, I. and Bettencourt-Dias, M. (2009) From Zero to Many: Control of Centriole Number in Development and Disease. Traffic, 10, 482-498. http://dx.doi.org/10.1111/j.1600-0854.2009.00905.x

[15] Delattre, M. and Gönczy, P. (2004) The Arithmetic of Centrosome Biogenesis. Journal of Cell Science, 117, 16191630. http://dx.doi.org/10.1242/jcs.01128

[16] Mennella, V., Agard, D.A., Huang, B. and Pelletier, L. (2014) Amorphous No More: Subdiffraction View of the Pericentriolar Material Architecture. Trends in Cell Biology, 24, 188-197. http://dx.doi.org/10.1016/j.tcb.2013.10.001

[17] Nigg, E.A. and Raft, J.W. (2009) Centrioles, Centrosomes, and Cilia in Health and Disease. Cell, 139, 663-678. http://dx.doi.org/10.1016/j.cell.2009.10.036

[18] Schafer, P.W. (1969) Centrioles of a Human Cancer: Intercellular Order and Intracellular Disorder. Science, 164, 13001303. http://dx.doi.org/10.1126/science.164.3885.1300

[19] Schafer, P.W. and Chandler, J.A. (1970) Electron Probe X-Ray Microanalysis of a Normal Centriole. Science, 170, 1204-1205. http://dx.doi.org/10.1126/science.170.3963.1204

[20] Harris, C.C., Autrup, H., Stoner, G.D., Trump, B.F., Hillman, E., Schafer, P.W. and Jeffrey, A.M. (1979) Metabolism of Benzo(a)pyrene, N-nitrosodimethylamine, and N-nitrosopyrrolidine and Identification of the Major CarcinogenDNA Adducts Formed in Cultured Human Esophagus. Cancer Research, 39, 4401-4406. 
[21] Schafer, P.W. (1972) Centrioles: Intercellular Order in Normal and Malignant Cells. The Journal of Thoracic and Cardiovascular Surgery, 63, 472-477.

[22] Marshall, W.F. and Rosenbaum, J.L. (2000) How Centrioles Work: Lessons from Green Yeast. Current Opinion in Cell Biology, 12, 119-125. http://dx.doi.org/10.1016/S0955-0674(99)00065-4

[23] Bornens, M. (2002) Centrosome Composition and Microtubule Anchoring Mechanisms. Current Opinion in Cell Biology, 14, 25-34. http://dx.doi.org/10.1016/S0955-0674(01)00290-3

[24] Lüders, J. and Stearns, T. (2007) Microtubule-Organizing Centres: A Re-Evaluation. Nature Reviews, Molecular Cell Biology, 8, 161-167. http://dx.doi.org/10.1038/nrm2100

[25] Rajagopalan, H. and Lengauer, C. (2004) Aneuploidy and Cancer. Nature, 432, 338-341. http://dx.doi.org/10.1038/nature03099

[26] Marshall, W. (2001) Centrioles Take Center Stage. Current Biology, 11, R487-R496. http://dx.doi.org/10.1016/s0960-9822(01)00289-5

[27] Watson, J.D. and Crick, E.H.C. (1953) Molecular Structure of Nucleic Acids: A Structure for Deoxyribose Nucleic Acid. Nature, 171, 737-738. http://dx.doi.org/10.1038/171737a0

[28] Duensing, A., Liu, Y., Perdreau, S.A., Kleylein-Sohn, J., Nigg, E.A. and Duensing, S. (2007) Centriole Overduplication through the Concurrent Formation of Multiple Daughter Centrioles at Single Material Templates. Oncogene, 26, 6280-6288. http://dx.doi.org/10.1038/sj.onc.1210456

[29] Schöckel, L., Möckel, M., Mayer, B., Boos, D. and Stemmann, O. (2011) Cleavage of Cohesion Rings Coordinates the Separation of Centrioles and Chromatids. Nature Cell Biology, 13, 966-972. http://dx.doi.org/10.1038/ncb2280

[30] Kobayashi, T. and Dynlacht, B.D. (2011) Regulating the Transition from Centriole to Basal Body. Journal of Cell Biology, 193, 435-444. http://dx.doi.org/10.1083/jcb.201101005

[31] Ganem, N.J., Godinho, S.A. and Pellman, D. (2009) A Mechanism Linking Extra Centrosomes to Chromosomal Instability. Nature, 460, 278-282. http://dx.doi.org/10.1038/nature08136

[32] Nigg, E.A. (2002) Centrosome Aberrations: Cause or Consequence of Cancer Progression? Nature Reviews Cancer, 2 , 815-825. http://dx.doi.org/10.1038/nrc924

[33] Korzeniewski, N., Hohenfellner, M. and Duensing, S. (2012) CANDI Promotes PLK4-Mediated Centriole Overduplication and Is Frequently Disrupted in Prostate Cancer. Neoplasia, 14, 799-806. http://dx.doi.org/10.1593/neo.12580

[34] Zyss, D. and Gergely, F. (2009) Centrosome Function in Cancer: Guilty or Innocent? Trends in Cell Biology, 19, 334346. http://dx.doi.org/10.1016/j.tcb.2009.04.001

[35] Hameroff, S.R. (2004) A New Theory of the Origin of Cancer: Quantum Coherent Entanglement, Centrioles, Mitosis, and Differentiation. Biosystems, 77, 119-136. http://dx.doi.org/10.1016/j.biosystems.2004.04.006

[36] Raff, J.W. (2002) Centrosomes and Cancer: Lessons from a TACC. Trends in Cell Biology, 12, 222-225. http://dx.doi.org/10.1016/S0962-8924(02)02268-7

[37] Salisbury, J.L., Whitehead, C.M., Lingle, W.L. and Barrett, S.L. (1999) Centrosomes and Cancer. Biology of the Cell, 91, 451-460. http://dx.doi.org/10.1111/j.1768-322X.1999.tb01100.x

[38] Cowan, C.R. and Hyman, A.A. (2004) Centrosomes Direct Cell Polarity Independently of Microtubule Assembly in C. elegans Embryos. Nature, 431, 92-96. http://dx.doi.org/10.1038/nature02825

[39] Godinho, S.A., Kwon, M. and Pellman, D. (2009) Centrosomes and Cancer: How Cancer Cells Divide with Too Many Centrosomes. Cancer Metastasis Review, 28, 85-98. http://dx.doi.org/10.1007/s10555-008-9163-6

[40] Oberringer, M., Lothschütz, D., Jennewein, M., Koschnick, M., Mutschler, W. and Hanselmann, R.G. (1999) Centrosomes Multiplication Accompanies a Transient Clustering of Polyploid Cells during Tissue Repair. Molecular Cell Biology Research Communications, 2, 190-196. http://dx.doi.org/10.1006/mcbr.1999.0172

[41] Sluder, G. and Nordberg, J.J. (2004) The Good, the Bad and the Ugly: The Practical Consequences of Centrosome Amplification. Current Opinion in Cell Biology, 16, 49-54. http://dx.doi.org/10.1016/j.ceb.2003.11.006

[42] Brinkley, B.R. (2001) Managing the Centrosome Numbers Game: From Chaos to Stability in Cancer Cell Division. Trends in Cell Biology, 11, 18-21. http://dx.doi.org/10.1016/S0962-8924(00)01872-9

[43] D’Assoro, A.B., Lingle, W.L. and Salisbury, J.L. (2002) Centrosome Amplification and the Development of Cancer. Oncogene, 21, 6146-6153. http://dx.doi.org/10.1038/sj.onc.1205772

[44] Hollander, M.C. and Fornace Jr., A.J. (2002) Genomic Instability Centrosome Amplification, Cell Cycle Checkpoints and Gadd45a. Oncogene, 21, 6228-6233. http://dx.doi.org/10.1038/sj.onc.1205774

[45] Basto, R., Brunk, K., Vinadogrova, T., Peel, N., Franz, A., Khodjakov, A. and Raff, J.W. (2008) Centrosome Amplification Can Initiate Tumorigenesis in Flies. Cell, 133, 1032-1042. http://dx.doi.org/10.1016/j.cell.2008.05.039 
[46] Pihan, G.A., Wallace, J., Zhou, Y. and Doxsey, S.J. (2003) Centrosome Abnormalities and Chromosome Instability Occur Together in Pre-Invasive Carcinomas. Cancer Research, 63, 1398-1404.

[47] Tsou, M.F. and Stearns, T. (2006) Mechanism Limiting Centrosome Duplication to Once Per Cell Cycle. Nature, 442, 947-951. http://dx.doi.org/10.1038/nature04985

[48] Bettencourt-Dias, M. and Glover, D.M (2009) SnapShot: Centriole Biogenesis. Cell, 136, 188.e1-188.e2. http://dx.doi.org/10.1016/j.cell.2008.12.035

[49] Löffler, H., Fechter, A., Liu, F.Y., Poppelreuther, S. and Krämer, A. (2013) DNA Damage-Induced Centrosome Amplification Occurs via Excessive Formation of Centriolar Satellites. Oncogene, 32, 2963-2972. http://dx.doi.org/10.1038/onc.2012.310

[50] Mycielska, M.E. and Djamgoz, M.B. (2004) Cellular Mechanisms of Direct-Current Electric Field Effects: Galvanotaxis and Metastatic Disease. Journal of Cell Science, 177, 1631-1639. http://dx.doi.org/10.1242/jcs.01125

[51] Lingle, W.L., Barrett, S.L., Negron, V.C., D’Assoro, A.B., Boeneman, K., Liu, W., Whitehead, C.M., Reynolds, C. and Salisbury, J.L. (2002) Centrosome Amplification Drives Chromosomal Instability in Breast Tumor Development. Proceedings of the National Academy of Sciences of the United States of America, 99, 1978-1983. http://dx.doi.org/10.1073/pnas.032479999

[52] Rodrigues-Martins, A., Riparbelli, M., Callaini, G., Glover, D.M. and Bettencourt-Dias, M. (2008) From Centriole Biogenesis to Cellular Function: Centrioles Are Essential for Cell Division at Critical Developmental Stages. Cell Cycle, 7, 11-16. http://dx.doi.org/10.4161/cc.7.1.5226

[53] Marthiens, V., Rujano, M.A., Pennetier, C., Tessier, S., Paul-Gilloteaux, P. and Basto, R. (2013) Centrosome Amplification Causes Microcephaly. Nature Cell Biology, 15, 731-742. http://dx.doi.org/10.1038/ncb2746

[54] Yang, Z., Loncarek, J., Khodjakov, A. and Rieder, C.I. (2008) Extra Centrosomes and/or Chromosomes Prolong Mitosis in Human Cells. Nature Cell Biology, 10, 748-751. http://dx.doi.org/10.1038/ncb1738

[55] Pearson, C.G. and Winey, M. (2010) Plk4/SAK/ZYG-1 in the Regulation of Centriole Duplication. F1000 Biology Reports, 2, 58.

[56] Eckerdt, F., Yamamoto, T.M., Lewellyn, A.L. and Maller, J.L. (2011) Identification of a Polo-Like Kinase 4-Dependent Pathway for de Novo Centriole Formation. Current Biology, 21, 428-432. http://dx.doi.org/10.1016/j.cub.2011.01.072

[57] Korzeniewski, N., Zheng, L., Cuevas, R., Parry, J., Chatterjee, P., Anderton, B., Duensing, A., Münger, K. and Duensing, S. (2009) Cullin 1 Functions as a Centrosomal Suppressor of Centriole Multiplication by Regulating Polo-Like Kinase 4 Protein Levels. Cancer Research, 69, 6668-6675. http://dx.doi.org/10.1158/0008-5472.CAN-09-1284

[58] Cunha-Ferreira, I., Rodrigues-Martins, A., Bento, I., Riparbelli, M., Zhang, W., Laue, E., Callaini, G., Glover, D.M. and Bettencourt-Dias, M. (2009) The SCF/Slimb Ubiquitin Ligase Limits Centrosome Amplification through Degradation of SAK/PLK4. Current Biology, 19, 43-49. http://dx.doi.org/10.1016/j.cub.2008.11.037

[59] Peel, N., Stevens, N.R., Basto, R. and Raff, J.W. (2007) Overexpressing Centriole-Replication Proteins in Vivo Induces Centriole Overduplication and de Novo Formation. Current Biology, 17, 834-843. http://dx.doi.org/10.1016/j.cub.2007.04.036

[60] Duensing, S. (2005) A Tentative Classification of Centrosome Abnormalities in Cancer. Cell Biology International, 29, 352-359. http://dx.doi.org/10.1016/j.cellbi.2005.03.005

[61] Nigg, E.A. and Stearns, T. (2011) The Centrosome Cycle: Centriole Biogenesis, Duplication and Inherent Asymmetries. Nature Cell Biology, 13, 1154-1160. http://dx.doi.org/10.1038/ncb2345

[62] Kleylein-Sohn, J., Westendorf, J., Le Clech, M., Habedanck, R., Stierhof, Y. and Nigg, E.A. (2007) Plk4-Induced Centriole Biogenesis in Human Cells. Developmental Cell, 13, 190-202. http://dx.doi.org/10.1016/j.devcel.2007.07.002

[63] Nigg, E.A. (2007) Centrosome Duplication: of Rules and Licenses. Trends in Cell Biology, 17, 215-221. http://dx.doi.org/10.1016/j.tcb.2007.03.003

[64] Nakazawa, Y., Hiraki, M., Kamiya, R. and Hirono, M. (2007) SAS-6 Is a Cartwheel Protein that Establishes the 9-Fold Symmetry of the Centriole. Current Biology, 17, 2169-2174. http://dx.doi.org/10.1016/j.cub.2007.11.046

[65] Strnad, P. and Gönczy, P. (2008) Mechanisms of Procentriole Formation. Trends in Cell Biology, 18, 389-396. http://dx.doi.org/10.1016/j.tcb.2008.06.004

[66] Pelletier, L., O’Toole, E., Schwager, A., Hyman, A.A. and Müller-Reichert, T. (2006) Centriole Assembly in Caenorhabditis elegans. Nature, 444, 619-623. http://dx.doi.org/10.1038/nature05318

[67] Goepfert, T.M., Adigun, Y.E., Zhong, L., Gay, J., Medina, D. and Brinkley, W.R. (2002) Centrosome Amplification and Overexpression of Aurora A Are Early Events in Rat Mammary Carcinogenesis. Cancer Research, 62, 4115-4122.

[68] Sonnen, K.F., Schermelleh, L., Leonhardt, H. and Nigg, E.A. (2012) 3D-Structured Illumination Microscopy Provides Novel Insight into Architecture of Human Centrosomes. Biology Open, 1, 965-976.

http://dx.doi.org/10.1242/bio.20122337 
[69] Wong, C. and Stearns, T. (2003) Centrosome Number Is Controlled by a Centrosome-Intrinsic Block to Reduplication. Nature Cell Biology, 5, 539-544. http://dx.doi.org/10.1038/ncb993

[70] Kawamura, K., Izumi, H., Ma, Z., Ikeda, R., Moriyama, M., Tanaka, T., Nojima, T., Levin, L.S., Fujikawa-Yamamoto, K., Suzuki, K. and Fukasawa, K. (2004)Induction of Centrosome Amplification and Chromosome Instability in Human Bladder Cancer Cells by p53 Mutation and Cyclin E Overexpression. Cancer Research, 64, 4800-4809. http://dx.doi.org/10.1158/0008-5472.CAN-03-3908

[71] Brownlee, C.W. and Rogers, G.C. (2013) Show Me Your License, Please: Deregulation of Centriole Duplication Mechanisms That Promote Amplification. Cellular and Molecular Life Sciences, 70, 1021-1034. http://dx.doi.org/10.1007/s00018-012-1102-6

[72] Tarapore, P., Horn, H.F., Tokuyama, Y. and Fukasawa, K. (2001) Direct Regulation of the Centrosome Duplication Cycle by the p53-p21 ${ }^{\text {Waf1/Cip1 }}$ Pathway. Oncogene, 20, 3173-3184. http://dx.doi.org/10.1038/sj.onc.1204424

[73] Lončarek, J., Herget, P. and Khodjakov, A. (2010) Centeriole Reduplication during Prolonged Interphase Requires Procentriole Maturation Governed by Plk1. Current Biology, 20, 1277-1282. http://dx.doi.org/10.1016/j.cub.2010.05.050

[74] Tsou, M.-F.B., Wang, W.-J., George, K.A., Uryu, K., Stearns, T. and Jallepalli, P.V. (2009) Polo Kinase and Separase Regulate the Mitotic Licensing of Centriole Duplication in Human Cells. Developmental Cell, 17, 344-354. http://dx.doi.org/10.1016/j.devcel.2009.07.015

[75] Barr, F.A., Silljé, H.H.W. and Nigg, E.A. (2004) Polo-Like Kinases and the Orchestration of Cell Division. Nature Reviews, Molecular Cell Biology, 5, 429-441.

[76] Aranda, V., Nolan, M.E. and Muthuswamy, S.K. (2008) Par Complex in Cancer: A Regulator of Normal Cell Polarity Joins the Dark Side. Oncogene, 27, 6878-6887. http://dx.doi.org/10.1038/onc.2008.340

[77] Kirkham, M., Müller-Reichart, T., Oegema, K., Grill, S. and Hymam, A.A. (2003) SAS-4 Is a C. elegens Centriolar Protein that Controls Centrosome Size. Cell, 112, 575-587. http://dx.doi.org/10.1016/S0092-8674(03)00117-X

[78] van Breugel, M., Hirono, M., Andreeva, A., Yanagisawa, H.A., Yamaguchi, S., Nakazawa, Y., Morgner, N., Petrovich, M., Ebong, I.O., Robinson, C.V., Johnson, C.M., Veprintsev, D. and Zuber, B. (2011) Structures of SAS-6 Suggest Its Organization in Centrioles. Science, 331, 1196-1199. http://dx.doi.org/10.1126/science.1199325

[79] Klebba, J.E., Galletta, B.J., Nye, J., Plevock, K.M., Buster, D.W., Hollingsworth, N.A., Slep, K.C., Rusan, N.M. and Rogers, G.C. (2015) Two Polo-Like Kinase 4 Binding Domains in Asterless Perform Distinct Roles in Regulating Kinase Stability. Journal of Cell Biology, 208, 401-414. http://dx.doi.org/10.1083/jcb.201410105

[80] Slevin, L.K., Nye, J., Pinkerton, D.C., Buster, D.W., Rogers, G.C. and Slep, K.C. (2012) The Structure of the Plk4 Cryptic Polo Box Reveals Two Tandem Polo Boxes Required for Centriole Duplication. Structure, 20, 1905-1917. http://dx.doi.org/10.1016/j.str.2012.08.025

[81] Blachon, S., Gopalakrishnan, J., Omori, Y., Polyanovsky, A., Church, A., Nicastro, D., Malicki, J. and Avidor-Reiss, T. (2008) Drosophila Asterless and Vertebrate CEP152 Are Orthologs Essential for Centriole Duplication. Genetics, 180, 2081-2094. http://dx.doi.org/10.1534/genetics.108.095141

[82] Hiraki, M., Nakazawa, Y., Kamiya, R. and Hirono, M. (2007) Bld10p Constitutes the Cartwheel-Spoke Tip and Stabilizes the 9-Fold Symmetry of the Centriole. Current Biology, 17, 1776-1783. http://dx.doi.org/10.1016/j.cub.2007.09.021

[83] van de Weerdt, B.C.M. and Medema, R.H. (2006) Polo-Like Kinases: A Team in Control of the Division. Cell Cycle, 5, 853-864. http://dx.doi.org/10.4161/cc.5.8.2692

[84] Brownlee, C.W., Klebba, J.E., Buster, D.W. and Rogers, G.C. (2011) The Protein Phosphatase 2A Regulatory Submit Twins Stabilizes Plk4 to Induce Centriole Amplification. Journal of Cell Biology, 195, 231-243. http://dx.doi.org/10.1083/jcb.201107086

[85] Leidel, S., Delattre, M., Cerutti, L., Baumer, K. and Gonczy, P. (2005) SAS-6 Defines a Protein Family Required for Centrosome Duplication in C. elegans and in Human Cells. Nature Cell Biology, 7, 115-125. http://dx.doi.org/10.1038/ncb1220

[86] Delattre, M., Canard, C. and Gonczy, P. (2006) Sequential Protein Recruitment in C. elegans Centriole Formation. Current Biology, 16, 1844-1849. http://dx.doi.org/10.1016/j.cub.2006.07.059

[87] Dutcher, S.K. (2003) Long-Lost Relatives Reappear: Identification of New Members of the Tubulin Superfamily. Current Opinion in Microbiology, 6, 634-640. http://dx.doi.org/10.1016/j.mib.2003.10.016

[88] Fu, J. and Glover, D.M. (2012) Structured Illumination of the Interface between Centriole and Peri-Centriolar Material. Open Biology, 2, Article ID: 120104. http://dx.doi.org/10.1098/rsob.120104

[89] Warnke, S., Kemmler, S., Hames, R.S., Tsai, H.L., Hoffmann-Rohrer, U., Fry, A.M. and Hoffmann, I. (2004) Polo-Like Kinase-2 Is Required for Centriole Duplication in Mammalian Cells. Current Biology, 14, 1200-1207. http://dx.doi.org/10.1016/j.cub.2004.06.059 
[90] Inclán, Y.F. and Nogales, E. (2000) Structural Models for the Self-Assembly and Microtubule Interactions of Gamma-, Delta- and Epsilon-Tubulin. Journal of Cell Science, 114, 413-422.

[91] Tassin, A.-M. and Bornens, M. (1999) Centrosome Structure and Microtubule Nucleation in Animal Cells. Biology of the Cell, 91, 343-354. http://dx.doi.org/10.1111/j.1768-322X.1999.tb01092.x

[92] Cuzick, J., Holland, R., Barth, V., Davies, R., Faupel, M., Fentiman, I., Frischbier, H.J., LaMarque, J.L., Merson, M., Sacchini, V., Vanel, D. and Veronesi, U. (1998) Electropotential Measurements as a New Diagnostic Modality for Breast Cancer. The Lancet, 352, 359-363. http://dx.doi.org/10.1016/S0140-6736(97)10002-2

[93] Krämer, A., Neben, K. and Ho, A.D. (2002) Centrosome Replication, Genomic Instability and Cancer. Leukemia, 16, 767-775. http://dx.doi.org/10.1038/sj.leu.2402454

[94] Gisselsson, D., Jonson, T., Yu, C., Martins, C., Mandahl, N., Wiegant, J., Jin, Y., Mertens, F. and Jin, C. (2002) Centrosomal Abnormalities, Multipolar Mitoses, and Chromosomal Instability in Head and Neck Tumours with Dysfunctional Telomeres. British Journal of Cancer, 87, 202-207. http://dx.doi.org/10.1038/sj.bjc.6600438

[95] Lončarek, J., Hergert, P., Magidson, V. and Khodjakov, A. (2008) Control of Daughter Centriole Formation by the Pericentriolar Material. Nature Cell Biology, 10, 322-328. http://dx.doi.org/10.1038/ncb1694

[96] Doxsey, S.J. (2001) Centrosomes as Command Centres for Cellular Control. Nature Cell Biology, 3, E105-E108. http://dx.doi.org/10.1038/35074618

[97] Nigg, E.A. (2001) Mitotic Kinases as Regulators of Cell Division and Its Checkpoints. Nature Reviews, Molecular Cell Biology, 2, 21-31. http://dx.doi.org/10.1038/35048096

[98] Korzeniewski, N., Hohenfellner, M. and Duensing, S. (2012) CANDI Promotes PLK4-Mediated Centriole Overduplication and Is Frequently Disrupted in Prostate Cancer. Neoplasia, 14, 799-806. http://dx.doi.org/10.1593/neo.12580

[99] Piel, M., Meyer, P., Khodjakov, A., Rieder, C.L. and Bornens, M. (2000) The Respective Contribution of the Mother and Daughter Centrioles to Centrosome Activity and Behavior in Vertebrate Cells. Journal of Cell Biology, 149, 317330. http://dx.doi.org/10.1083/jcb.149.2.317

[100] Lange, B.M. and Gull, K. (1995) A Molecular Marker for Centriole Maturation in the Mammalian Cell Cycle. The Journal of Cell Biology, 130, 919-927. http://dx.doi.org/10.1083/jcb.130.4.919

[101] Stucke, V.M., Silljé, H.H.W., Arnaud, L. and Nigg, E.A. (2002) Human Mps1 Kinase Is Required for the Spindle Assembly Checkpoint but Not for Centrosome Duplication. The EMBO Journal, 21, 1723-1732. http://dx.doi.org/10.1093/emboj/21.7.1723

[102] Blagden, S.P. and Glover, D.M. (2003) Polar Expeditions—Provisioning the Centrosome for Mitosis. Nature Cell Biology, 5, 505-511. http://dx.doi.org/10.1038/ncb0603-505

[103] Cheng, K. and Zou, C. (2006) Physics Models of Centriole Replication. Medical Hypotheses, 67, 572-577. http://dx.doi.org/10.1016/j.mehy.2006.02.041

[104] Huston, R.L. (2014) On Centrioles, Microtubules, and Cellular Electromagnetism. Journal of Nanotechnology in Engineering and Medicine, 5, Article ID: 031003.

[105] Huston, R.L. (2015) Using the Electromagnetics of Cancer's Centrosome Clusters to Attract Therapeutic Nanoparticles. Advances in Bioscience and Biotechnology, 6, 172-181. http://dx.doi.org/10.4236/abb.2015.63017

[106] Ridley, A. and Heald, R. (2011) Cell Structure and Dynamics-Editorial overview. Current Opinion in Cell Biology, 23, 1-3. http://dx.doi.org/10.1016/j.ceb.2010.12.003

[107] Doxsey, S., McCollum, D. and Theurkauf, W. (2005) Centrosomes in Cellular Regulation. Annual Review of Cell and Developmental Biology, 21, 411-434. http://dx.doi.org/10.1146/annurev.cellbio.21.122303.120418

[108] Lawo, S., Hasegan, M., Gupta, G.D. and Pelletier, L. (2012) Subdiffraction Imaging of Centrosomes Reveals Higher-Order Organizational Features of Pericentriolar Material. Nature Cell Biology, 14, 1148-1158. http://dx.doi.org/10.1038/ncb2591

[109] Azimzadeh, J. and Bornens, M. (2007) Structure and Duplication of the Centrosome. Journal of Cell Science, 120, 2139-2142. http://dx.doi.org/10.1242/jcs.005231

[110] Avidor-Reiss, T. and Gopalakrishnan, J. (2013) Building a Centriole. Current Opinion in Cell Biology, 25, 72-77. http://dx.doi.org/10.1016/j.ceb.2012.10.016

[111] Gopalakrishnan, J., Guichard, P., Smith, A.H., Schwarz, H., Agard, D.A., Marco, S. and Avidor-Reiss, T. (2010) SelfAssembling SAS-6 Multimer Is a Core Centriole Building Block. The Journal of Biological Chemistry, 285, 87598770. http://dx.doi.org/10.1074/jbc.M109.092627

[112] Habedanck, R., Stierhof, Y.-D., Wilkinson, C.J. and Nigg, E.A. (2005) The Polo Kinase Plk4 Functions in Centriole Duplication. Nature Cell Biology, 7, 1140-1146. http://dx.doi.org/10.1038/ncb1320

[113] Hatch, E.M., Kulukian, A., Holland, A.J., Cleveland, D.W. and Stearns, T. (2010) Cep152 Interacts with Plk4 and Is Required for Centriole Duplication. Journal of Cell Biology, 191, 721-729. http://dx.doi.org/10.1083/jcb.201006049 
[114] Vitre, B.D. and Cleveland, D.W. (2012) Centrosomes, Chromosome Instability (CIN) and Aneuploidy. Current Opinion in Cell Biology, 24, 809-815. http://dx.doi.org/10.1016/j.ceb.2012.10.006

[115] Arquint, C., Sonnen, K.F., Stierhof, Y.-D. and Nigg, E.A. (2012) Cell-Cycle-Regulated Expression of STIL Controls Centriole Number in Human Cells. Journal of Cell Science, 125, 1342-1352. http://dx.doi.org/10.1242/jcs.099887

[116] Holland, A.J., Lan, W., Niessen, S., Hoover, H. and Cleveland, D.W. (2010) Polo-Like Kinase 4 Kinase Activity Limits Centrosome Overduplication by Autoregulating Its Own Stability. The Journal of Cell Biology, 188, 191-198. http://dx.doi.org/10.1083/jcb.200911102

[117] Lingle, W.L. and Salisbury, J.L. (2000) The Role of the Centrosome in the Development of Malignant Tumors. Current Topics in Developmental Biology, 49, 313-339. http://dx.doi.org/10.1016/S0070-2153(99)49015-5

[118] Marx, J. (2001) Do Centrosome Abnormalities Lead to Cancer? Science, 292, 426-429. http://dx.doi.org/10.1126/science.292.5516.426

[119] Baffet, A.D., Martin, C.A., Scarfone, I., Daley, O.M., David, A., Tibelius, A., Lattao, R., Hussain, M.S. and Woodruff, J.B. (2013) Meeting Report-Building a Centrosome. Journal of Cell Science, 126, 3259-3262. http://dx.doi.org/10.1242/jcs.136721

[120] Mogensen, M.M., Malik, A., Piel, M., Bouckson-Castaing, V. and Bornens, M. (2000) Microtuble Minus-End Anchorage at Centrosomal and Non-Centrosomal Sites: The Role of Ninein. Journal of Cell Science, 113, 3013-3023. http://dx.doi.org/10.1016/j.devcel.2004.10.015

[121] Dammermann, A., Müller-Reichert, T., Pelletier, L., Habermann, B., Desai, A. and Oegema, K. (2004) Centriole Assembly Requires Both Centriolar and Pericentriolar Material Proteins. Developmental Cell, 7, 815-829.

[122] Bettencourt-Dias, M., Rodrigues-Martins, A., Carpenter, L., Riparbelli, M., Lehmann, L., Gatt, M.K., Carmo, N., Balloux, F., Callaini, G. and Glover, D.M. (2005) SAK/PLK4 Is Required for Centriole Duplication and Flagella Development. Current Biology, 15, 2199-2207. http://dx.doi.org/10.1016/j.cub.2005.11.042

[123] Marthiens, V., Piel, M. and Basto, R. (2012) Never Tear Us Apart-The Importance of Centrosome Clustering. Journal of Cell Science, 125, 3281-3292. http://dx.doi.org/10.1242/jcs.094797

[124] Lacey, K.R., Jackson, P.K. and Stearns, T. (1999) Cyclin-Dependent Kinase Control of Centrosome Duplication. Proceedings National Academy of Sciences of the United States of America, 96, 2817-2822. http://dx.doi.org/10.1073/pnas.96.6.2817

[125] Rodrigues-Martins, A., Riparbelli, M., Callaini, G., Glover, D.M. and Bettencourt-Dias, M. (2007) Revisiting the Role of the Mother Centriole in Centriole Biogenesis. Science, 316, 1046-1050. http://dx.doi.org/10.1126/science.1142950

[126] Bettencourt-Dias, M. and Glover, D.M. (2007) Centrosome Biogenesis and Function: Centrosomics Brings New Understanding. Nature Reviews, Molecular Cell Biology, 8, 451-463. http://dx.doi.org/10.1038/nrm2180

[127] Kohlmaier, G., Lončarek, J., Meng, X., McEwen, B.F., Mogensen, M.M., Spektor, A., Dynlacht, B.D., Khodjakov, A. and Gönczy, P. (2009) Overly Long Centrioles and Defective Cell Division upon Excess of the SAS-4-Related Protein CPAP. Current Biology, 19, 1012-1018. http://dx.doi.org/10.1016/j.cub.2009.05.018

[128] Kong, D., Farmer, V., Shukla, A., James, J., Gruskin, R., Kiriyama, S. and Loncarek, J. (2014) Centriole Maturation Requires Regulated Plk1 Activity during Two Consecutive Cell Cycles. Journal of Cell Biology, 206, 855-865. http://dx.doi.org/10.1083/jcb.201407087

[129] Klebba, J.E., Buster, D.W., McLamarrah, T.A., Rusan, N.M. and Rogers, G.C. (2015) Autoinhibition and Relief Mechanism for Polo-Like Kinase 4. Proceedings National Academy of Sciences of the United States of America, 112, E657-E666. http://dx.doi.org/10.1073/pnas.1417967112

[130] Sonnen, K.F., Gabryjonczyk, A.M., Anselm, E., Stierhof, Y.D. and Nigg, E.A. (2014) Human Cep192 and Cep152 Cooperate in Plk4 Recruitment and Centriole Duplication. Journal of Cell Science, 126, 3223-3233. http://dx.doi.org/10.1242/jcs.129502

[131] Dzhindzhev, N.S., Yu, Q.D., Weiskopf, K., Tzolovsky, G., Cunha-Ferreira, I., Riparbelli, M., Rodrigues-Martins, A., Bettencourt-Dias, M., Callaini, G. and Glover, D.M. (2010) Asterless Is a Scaffold for the Onset of Centriole Assembly. Nature, 457, 714-718. http://dx.doi.org/10.1038/nature09445

[132] Cunha-Ferreira, I., Bento, I., Pimenta-Marques, A., Jana, S.C., Lince-Faria, M., Duarte, P., Borrego-Pinto, J., Gilberto, S., Amado, T., Brito, D., Rodrigues-Martins, A., Debski, J., Dzhindzhev, N. and Bettencourt-Dias, M. (2013) Regulation of Autophosphorylation Controls PLK4 Self-Destruction and Centriole Number. Current Biology, 23, $2245-2254$. http://dx.doi.org/10.1016/j.cub.2013.09.037

[133] Klebba, J.E., Buster, D.W., Nguyen, A.L., Swatkoski, S., Gucek, M., Rusan, N.M. and Rogers, G.C. (2013) Polo-Like Kinase 4 Autodestructs by Generating Its Slimb-Binding Phosphodegron. Current Biology, 23, 2255-2261. http://dx.doi.org/10.1016/j.cub.2013.09.019

[134] Wiese, C. and Zheng, Y. (2000) A New Function for the Gamma-tubulin Ring Complex as a Microtubule Minus-End Cap. Nature Cell Biology, 2, 358-364. http://dx.doi.org/10.1038/35014051 
[135] Varmark, H., Llamazares, S., Rebollo, E., Lange, B., Reina, J., Schwarz, H. and Gonzalez, C. (2007) Asterless Is a Centriolar Protein Required for Centrosome Function and Embryo Development in Drosophila. Current Biology, 17, 1735-1745. http://dx.doi.org/10.1016/j.cub.2007.09.031

[136] Fukasawa, K., Choi, T., Kuriyama, P., Rulong, S. and Vande Woude, G.F. (1996) Abnormal Centrosome Amplification in the Absence of P53. Science, 271, 1744-1747. http://dx.doi.org/10.1126/science.271.5256.1744

[137] Borel, F., Lohez, O.D., Lacroix, F.B. and Margolis, R.L. (2002) Multiple Centrosomes Arise from Tetraploidy Checkpoint Failure and Mitotic Centrosome Clusters in p53 and RB Pocket Protein-Compromised Cells. Proceedings National Academy of Sciences of the United States of America, 99, 9819-9824. http://dx.doi.org/10.1073/pnas.152205299

[138] Shinmura, K., Bennett, R.A., Tarapore, P. and Fukasawa, K. (2007) Direct Evidence for the Role of Centrosomally Localized p53 in the Regulation of Centrosome Duplication. Oncogene, 26, 2939-2944. http://dx.doi.org/10.1038/sj.onc.1210085

[139] Tarapore, P. and Fukasawa, K. (2002) Loss of p53 and Centrosome Hyperamplification. Oncogene, 21, 6234-6240. http://dx.doi.org/10.1038/sj.onc.1205707

[140] Fukasawa, K. (2005) Centrosome Amplification, Chromosome Instability and Cancer Development. Cancer Letters, 230, 6-19. http://dx.doi.org/10.1016/j.canlet.2004.12.028

[141] Saunders, W. (2005) Centrosomal Amplification and Spindle Multipolarity in Cancer Cells. Seminars in Cancer Biology, 15, 25-32. http://dx.doi.org/10.1016/j.semcancer.2004.09.003

[142] Kasbek, C., Yang, C.-H., Yusof, A.M., Chapman, H.M., Winey, M. and Fisk, H.A. (2007) Preventing the Degradation of Mps1 at Centrosomes Is Sufficient to Cause Centrosome Reduplication in Human Cells. Molecular Biology of the Cell, 18, 4457-4469. http://dx.doi.org/10.1091/mbc.E07-03-0283

[143] Mayor, T., Stierhof, Y.-D., Tanaka, K., Fry, A.M. and Nigg, E.A. (2000) The Centrosomal Protein C-Nap1 Is Required for Cell Cycle-Regulated Centrosome Cohesion. The Journal of Cell Biology, 151, 837-846. http://dx.doi.org/10.1083/jcb.151.4.837

[144] Petronczki, M., Glotzer, M., Kraut, N. and Peters, J.-M. (2007) Polo-Like Kinase 1 Triggers the Initiation of Cytokinesis in Human Cells by Promoting Recruitment of the RhoGEF Ect2 to the Central Spindle. Developmental Cell, 12, 713-725. http://dx.doi.org/10.1016/j.devcel.2007.03.013

[145] Doxsey, S. (2002) Duplicating Dangerously: Linking Centrosome Duplication and Aneuploidy. Molecular Cell, 10, 439-440. http://dx.doi.org/10.1016/S1097-2765(02)00654-8

[146] Song, M.H., Miliaras, N.B., Peel, N. and O’Connell, K.F. (2008) Centrioles: Some Self-Assembly Required. Current Opinions in Cell Biology, 20, 688-693. http://dx.doi.org/10.1016/j.ceb.2008.09.001

[147] Nam, H.-J. and van Deursen, J.M. (2014) Cyclin B2 and p53 Control Proper Timing of Centrosome Separation. Nature Cell Biology, 16, 538-549. http://dx.doi.org/10.1038/ncb2952

[148] Elting, M.W., Hueschen, C.L., Udy, D.B. and Dumont, S. (2014) Force on Spindle Microtubule Minus Ends Moves Chromosomes. Journal of Cell Biology, 206, 245-256. http://dx.doi.org/10.1083/jcb.201401091

[149] Sillibourne, J.E., Tack, F., Vloemans, N., Boeckx, A., Thambirajah, S., Bonnet, P., Ramaekers, F.C., Bornens, M. and Grand-Perret, T. (2010) Autophosphorylation of Polo-Like Kinase 4 and Its Role in Centriole Duplication. Molecular Biology of the Cell, 21, 547-561. http://dx.doi.org/10.1091/mbc.E09-06-0505

[150] Cizmecioglu, O., Arnold, M., Bahtz, R., Settele, F., Ehret, L., Haselmann-Weiss, U., Antony, C. and Hoffmann, I. (2010) Cep152 Acts as a Scaffold for Recruitment of Plk4 and CPAP to the Centrosome. Journal of Cell Biology, 191, 731-739.

[151] Holland, A.J., Fachinetti, D., Zhu, Q., Bauer, M., Verma, I.M., Nigg, E.A. and Cleveland, D.W. (2012) The Autoregulated Instability of Polo-Like Kinase 4 Limits Centrosome Duplication to Once per Cell Cycle. Genes and Development, 26, 2684-2689. http://dx.doi.org/10.1101/gad.207027.112

[152] Duensing, A. and Duensing, S. (2005) Guilt by Association? P53 and the Development of Aneuploidy in Cancer. Biochemical and Biophysical Research Communications, 331, 694-700. http://dx.doi.org/10.1016/j.bbrc.2005.03.157

[153] Dammermann, A., Maddox, P.S., Desai, A. and Oegema, K. (2008) SAS-4 Is Recruited to a Dynamic Structure in Newly Forming Centrioles That Is Stabilized by the $\gamma$-Tubulin-Mediated Addition of Centriolar Microtubules. Journal of Cell Biology, 180, 771-785. http://dx.doi.org/10.1083/jcb.200709102

[154] Meggs, W.J. (1988) Electric Fields Deforming the Spatial Organization of Microtubules and Actin Filaments. Medical Hypothesis, 26, 165-170. http://dx.doi.org/10.1016/0306-9877(88)90095-3

[155] Kwon, M., Godinho, S.A., Chandhok, N.S., Ganem, N.J., Azioune, A., Thery, M. and Pellman, D. (2008) Mechanisms to Suppress Multipolar Divisions in Cancer Cells with Extra Chromosomes. Genes \& Development, 22, 2189-2203. http://dx.doi.org/10.1101/gad.1700908

[156] Doxey, S. (1998) The Centrosome_A Tiny Organelle with Big Potential. Nature Genetics, 20, 104-106. http://dx.doi.org/10.1038/2392 
[157] Fukasawa, K. (2007) Oncogenes and Tumour Suppressors Take on Centrosomes. Nature Reviews Cancer, 7, 911-924. http://dx.doi.org/10.1038/nrc2249

[158] Chan, J.Y. (2011) A Clinical Overview of Centrosome Amplification in Human Cancers. International Journal of Biological Sciences, 7, 1122-1144. http://dx.doi.org/10.7150/ijbs.7.1122

[159] Fukasawa, K. (2002) Introduction. Oncogene, 21, 6140-6145. http://dx.doi.org/10.1038/sj.onc.1205771

[160] Saavedra, H.I., Maiti, B., Timmers, C., Altura, R., Tokuyama, Y., Fukasawa, K. and Leone, G. (2003) Inactivation of E2F3 Results in Centrosome Amplification. Cancer Cell, 3, 333-346. http://dx.doi.org/10.1016/S1535-6108(03)00083-7

[161] Bettencourt-Dias, M., Hildebrandt, F., Pellman, D., Woods, G. and Godinho, S.A. (2011) Centrosomes and Cilia in Human Disease. Trends in Genetics, 27, 307-315. http://dx.doi.org/10.1016/j.tig.2011.05.004

[162] Sabino, D., Gogendeau, D., Gambarotto, D., Nano, M., Pennetier, C., Dingli, F., Arras, G., Loew, D. and Basto, R. (2105) Moesin Is a Major Regulator of Centrosome Behavior in Epithelial Cells with Extra Centrosomes. Current Biology, 25, 879-89. http://dx.doi.org/10.1016/j.cub.2015.01.066

[163] Khodjakov, A. and Rieder, C.L. (2001) Centrosomes Enhance the Fidelity of Cytokinesis in Vertebrates and Are Required for Cell Cycle Progression. The Journal of Cell Biology, 153, 237-242. http://dx.doi.org/10.1083/jcb.153.1.237

[164] Mahjoub, M.R. and Stearns, T. (2012) Supernumerary Centrosomes Nucleate Extra Cilia and Compromise Primary Cilium Signaling. Current Biology, 22, 1628-1634. http://dx.doi.org/10.1016/j.cub.2012.06.057

[165] Vulprecht, J., David, A., Tibelius, A., Castiel, A., Konotop, G., Liu, F., Bestvater, F., Raab, M.S., Zentgraf, H., Izraeli, S. and Krämer, A. (2012) STIL Is Required for Centriole Duplication in Human Cells. Journal of Cell Science, 125, 1353-1362. http://dx.doi.org/10.1242/jcs.104109

[166] Nakajima, T., Moriguchi, M., Mitsumoto, Y., Sekoguchi, S., Nishikawa, T., Takashima, H., Watanabe, T., Katagishi, T., Kimura, H., Okanoue, T. and Kagawa, K. (2004) Centrosome Aberration Accompanied with p53 Mutation Can Induce Genetic Instability in Hepatocellular Carcinoma. Modern Pathology, 17, 722-727. http://dx.doi.org/10.1038/modpathol.3800115

[167] Meraldi, P., Honda, R. and Nigg, E.A. (2002) Aurora-A Overexpression Reveals Tetraploidization as a Major Route to Centrosome Amplification in p53 ${ }^{-/}$Cells. The EMBO Journal, 21, 483-492. http://dx.doi.org/10.1093/emboj/21.4.483

[168] Duensing, A., Spardy, N., Chatterjee, P., Zheng, L., Parry, J., Cuevas, R., Korzeniewski, N. and Duensing, S. (2009) Centrosome Overduplication Chromosomal Instability, and Human Papillomavirus Oncoproteins. Environmental and Molecular Mutagenesis, 40, 741-747. http://dx.doi.org/10.1002/em.20478

[169] Garci-Bennett, A., Nees, M. and Fadeel, B. (2011) In Search of the Holy Grail: Folate-Targeted Nanoparticles for Cancer Therapy. Biochemical Pharmacology, 81, 976-984. http://dx.doi.org/10.1016/j.bcp.2011.01.023

[170] Lin, T.-C., Neuner, A. and Schiebel, E. (2015) Targeting of $\gamma$-Tubulin Complexes to Microtubule Organizing Centers: Conservation and Divergence. Trends in Cell Biology, 25, 296-307. http://dx.doi.org/10.1016/j.tcb.2014.12.002

[171] Cuzick, J., Holland, R., Barth, V., Davies, R., Faupel, M., Fentiman, I., Frischbier, H.J., LaMarque, J.L., Merson, M., Sacchini, V., Vanel, D. and Veronesi, U. (1998) Electropotential Measurements as a New Diagnostic Modality for Breast Cancer. The Lancet, 352, 359-363. http://dx.doi.org/10.1016/S0140-6736(97)10002-2

[172] Zhao, M., Bai, H., Wang, E., Forrester, J.V. and McCaig, C.D. (2004) Electrical Stimulation Directly Induced Pre-Angiogenic Responses in Vascular Endothelial Cells by Signaling through YEGF Receptors. Journal of Cell Science, 117, 397-405. http://dx.doi.org/10.1242/jcs.00868 